\title{
Wintering North Pacific black-legged kittiwakes balance spatial flexibility and consistency
}

Rachael A. Orben ${ }^{1,2^{*}}$ (D), Rosana Paredes ${ }^{3}$, Daniel D. Roby ${ }^{4}$, David B. Irons ${ }^{5}$ and Scott A. Shaffer ${ }^{6,7}$

\begin{abstract}
Background: Marine environments are inherently dynamic, yet marine predators are often long-lived and employ strategies where consistency, individual specialization, routine migrations, and spatial memory are key components to their foraging and life-history strategies. Intrinsic determinates of animal movements are linked to physiological and life-history traits (e.g. sex, colony, experience), while extrinsic influences occur as the result of an animal's interactions with either other animals or the environment (e.g. prey availability, weather, competition). Knowledge of the factors affecting animal movements is critical to understand energetic bottlenecks and population dynamics. Here, we attempt to understand the interaction of some of these factors on the winter distributions of a surface-feeding seabird in the North Pacific. Between 2008 and 2011, we tracked 99 black-legged kittiwakes breeding at St. Paul and St. George in the Pribilof Islands, Alaska using geolocation loggers. We tested for colony and sex differences in winter distributions, and individual spatial fidelity over two consecutive winters of 17 individuals. Then we linked tracking data to associated environmental conditions as proxies of prey availability (e.g. sea surface temperature, mesoscale eddies, chlorophyll a, and wind) to understand their influence on kittiwake space use at an ocean basin scale.
\end{abstract}

Results: Black-legged kittiwakes from both Pribilof Islands primarily wintered in pelagic sub-arctic waters, however, distributions spanned seven ecoregions of the North Pacific. There was a high degree of similarity in area use of birds from the two closely situated colonies and between sexes. Birds tracked for two consecutive years showed higher fidelity to wintering areas than occurred at random. Annual changes were apparent, as distributions were further north in 2009/10 than 2008/09 or 2010/11. This occurred because $70 \%$ of birds remained in the Bering Sea in the fall of 2009, which corresponded with lower October sea surface temperatures than the other two years.

Conclusions: Although individuals returned to wintering areas in consecutive years, our results suggest that under current conditions individual black-legged kittiwakes have a high capacity to alter winter distributions.

Keywords: Black-legged kittiwake, Rissa tridactyla, Non-breeding, Geolocation, Bering Sea, Colony, Sex, Fidelity, Oceanographic habitats

\section{Background}

Marine environments are inherently dynamic, yet marine predators are often long-lived and employ strategies where consistency, individual specialization, routine migrations, and spatial memory are key components to their foraging and life-history strategies [1-3]. At small scales, prey species such as squid, fish, and krill are patchily distributed-both vertically and horizontally in

\footnotetext{
* Correspondence: raorben@gmail.com

'Department of Ocean Sciences, Long Marine Lab, University of California Santa Cruz, Santa Cruz, CA 95060, USA

${ }^{2}$ Department of Fisheries and Wildlife, Oregon State University, Hatfield Marine Science Center, 2030 SE Marine Science Dr., Newport, OR 97365, USA Full list of author information is available at the end of the article
}

the water column $[4,5]$. Surface foraging seabirds are adapted to find food at small scales through social communication, olfactory and visual cues [6,7]. During the non-breeding period many of these species travel thousands of kilometers to upwelling regions and frontal zones where prey are more predictable $[8,9]$. This results in individuals choosing migratory destinations at an ocean basin scale, presumably without knowledge of conditions at their destinations [10].

Where and how animals move across a landscape is driven by a myriad of factors than can be simplified into intrinsic or extrinsic factors $[11,12]$. Intrinsic determinates of animal movements are linked to physiological and life-history traits of species (e.g. reproductive status, 
past experience, physiological needs and capacity, navigation abilities), while extrinsic influences occur as the result of an animal's interactions with either other animals or the environment (e.g. competition, predation, prey availability). While disentangling intrinsic and extrinsic factors and understanding how they may interact is difficult [13], intrinsic factors appear to be particularly important. For example, for seabirds, age, sex, and breeding colony may influence migrations [14-18]. As a consequence, these differences imply individuals within populations will be differentially affected by extrinsic factors such as prey availability. Furthermore, there is undoubtedly an influence of past experience and learning that shapes some portion of migratory paths, wintering areas, and prey preferences in long-lived seabirds [19-24]. Yet, over a lifetime individuals are likely to be flexible in their foraging choices as oceanic habitats are dynamic and conditions change from one season to the next $[25,26]$. Understanding how intrinsic and extrinsic factors interact to influence animal movements is paramount for an understanding of population trends and spatial capacity, particularly in highly mobile long-lived species.

Black-legged kittiwakes show spatial and dietary variability in foraging habitats both within and between colonies [27, 28], and throughout the annual cycle, including the winter non-breeding period [29-33]. Breeding individuals are known to display marked fidelity to locations and foraging in concert with tidal cycles [34], yet little is known about the importance of fidelity during the non-breeding period (but see [35]). In this study, we use the black-legged kittiwake as a model species to understand the importance of flexibility and consistency during their winter migrations to the dynamic pelagic environment. First we address the effects of breeding colony location, sex, and individual experience on the winter distributions of the black-legged kittiwake breeding at the Pribilof Islands. Then, we link three winters of kittiwake tracking data to associated environmental conditions and oceanic habitats to understand how annual habitat conditions influence space use at an ocean basin scale.

\section{Methods}

To study black-legged kittiwake (hereafter kittiwake) wintering ecology, geolocation loggers $(1.8 / 2.5 / 2.5 \mathrm{~g}$, Mk13/Mk9/Mk19, British Antarctic Survey, Cambridge UK) were deployed on 157 kittiwakes during July of 2008-2010 at two colonies in the Pribilof Islands, Alaska (St. Paul Island, 57.17N 169.60W and St. George Island, $56.60 \mathrm{~N}$ 169.60W; Table 1). All birds were captured off active nests using either a noose pole or foot snare supplemented with a $\mathrm{CO}_{2}$ powered net gun containing custom nets (Super Talon Animal Catcher, Advanced
Table 1 Sample sizes of black-legged kittiwakes (Rissa tridactyla) on which geolocation loggers (GLS) were deployed, resighted and recaptured

\begin{tabular}{rllll}
\hline & 2008 & 2009 & 2010 & Total \\
\hline $\begin{array}{rlll}\text { St Paul } \\
\text { deployed }\end{array}$ & $27^{\mathrm{a}}$ & $24^{\mathrm{b}, \mathrm{c}}$ & 31 & 82 \\
resighted & $23(85 \%)$ & $19(79 \%)$ & $27(87 \%)$ & $69(84 \%)$ \\
$\begin{array}{r}\text { recaught } \\
\text { St George }\end{array}$ & $22(81 \%)$ & $18(75 \%)$ & $19(61 \%)$ & $59(72 \%)$ \\
deployed & $30^{\mathrm{e}}$ & $17^{\mathrm{f}}$ & 28 & 75 \\
resighted & $26(87 \%)$ & $15(88 \%)$ & $26^{f}(92 \%)$ & $67(89 \%)$ \\
recaught & $22(73 \%)$ & $15(88 \%)$ & $25(89 \%)$ & $62(83 \%)$ \\
\hline
\end{tabular}

Birds were not individually marked in 2008 so resights rely on birds attending the same nests in subsequent years. Like recaptures, resights presented are cumulative, so birds from 2008 had three seasons of following effort, while birds from 2010 only had one year of recapture and resighting effort. Our objective was to recatch rather than resight birds, which often required hiding from birds rather than reading alphanumeric bands. Most birds were deployed with GPS and GLS loggers for a summer foraging study [27, 28], were subsequently recaptured and GLS loggers redeployed for overwinter. Thus deployment numbers also include 7 birds that were not recaptured during the summer breeding season (GPS tags fell off when tail feathers were molted); subsequently only 2 of these birds were recaught or resighted. Omitting these birds (and those whose nesting ledges fell) gives an overall resight of $91 \%$ a Includes 1 bird deployed for the summer with a GPS and a GLS logger; the GPS was not recovered and the bird was not resighted in subsequent seasons b 3 birds were deployed in on a cliff face that collapsed overwinter and never resighted. These birds may have relocated to other areas of the colony where, due to the size of the cliffs, we were unable to resight them

' Includes 2 birds deployed for the summer with a GPS and a GLS logger; the GPS was not recovered and birds were not resighted in subsequent seasons

${ }^{d}$ Includes 2 birds deployed with both a GPS and GLS logger; the GPS was not recovered. 1 bird was recaught with a GLS logger in 2009, the other was not resighted

${ }^{\mathrm{e}}$ Includes 2 birds deployed with both a GPS and GLS logger; the GPS was not recovered. 1 bird was recaught with a GLS logger in 2010, the other was not resighted

${ }^{f}$ High Bluffs, where 2 GLS loggers were deployed in 2010, was only visited twice in 2011 and 1 bird was never seen

Weapons Technology, California) at recapture. At deployment and recapture birds were weighed and measured, nest contents were recorded and blood samples for sexing via DNA were taken [36]. Overall, $86.6 \%$ of birds were resighted and $77 \%$ of loggers were recovered (Table 1). Seven loggers failed during data recovery and 13 loggers failed before recapture. Over the three study winters, 17 birds carried loggers for 2 winters. A total of 113 complete winter trips were recorded from 99 kittiwakes. It is possible that though the loggers used in this study were small $(\sim 0.6 \%$ body mass or less) they still may have had deleterious effects on the individuals carrying them [37, 38], however no negative effects have been thus far reported for kittiwakes carrying geolocation loggers in terms of body mass, breeding participation or survival [29, 31, 32].

Data processing, spatial analyses and statistical tests were conducted using MATLAB (v2014a, The Mathworks, Natick, MA) and R v3.1.1 (R Development Core Team, 2014). Significance was set to $p<0.05$. 


\section{Geolocation processing}

Geolocations were estimated from September 1 thru May 30 with the colony as a fixed start and end location using the 'TripEstimation' package in $\mathrm{R}$ to implement a Bayesian model that incorporates a land mask and flight speed into the prior distribution and calculates locations from light levels using the 'template-fit' method [39-41]. We used a mean speed of $33 \mathrm{~km} \mathrm{hr}^{-1}$ [42], however tag derived activity data (time spent dry, [32]) indicated that birds only spent $15 \pm 9 \%$ of each $24 \mathrm{hr}$ period flying, therefore, as a conservative estimate we chose to assume that birds spent $33 \%$ (two standard deviations from the mean) of their time in flight, restricting an individual's range over 12 hours, on average, to $130 \mathrm{~km}$. Thus a mean speed of $10.89 \mathrm{~km} \mathrm{hr}^{-1}$ and speed variance equal to half this were entered into the model to parameterize a lognormal distribution. The most probable track was then obtained through a Kalman filter with six Markov Chain Monte Carlo (MCMC) simulations of 1000 iterations each, after a 500-iteration burn in period. Tracks were visually compared and found to be similar to those calculated using smoothing and filtering methods that result in errors of $186 \pm 114 \mathrm{~km}$ [43]. Subsequently, all analysis were constrained to October thru February to avoid greater errors inherent in locations estimated around the equinox period.

\section{Distributions}

How birds share space over large scales relates to the size of individual ranges, the distribution of these ranges, and the density of birds. Individual range size was calculated as the number of $45 \times 45 \mathrm{~km}$ grid squares occupied by the last chain of the MCMC estimation (1000 iterative tracks). To assess how variable each group (colony, sex, year) was in the areas they used as well as a quantitative assessment of sample sizes, the cumulative number of grid cells occupied was calculated with the addition of one track from each individual randomly selected for 10,000 iterations [44]. Groups with less variability or higher amounts of area shared between individuals, have shallower curves than groups with high individual variability in area use [44]. To assess the amount of shared area, an index of similarity was calculated as the ratio of the number of shared grid cells $(45 \mathrm{~km})$ occupied by the last chain of the MCMC estimation to the total grid cells used by both groups, where identical groups would be equal to 1 . To test these indexes against what similarity might randomly occur, birds were randomly assigned to groups and the index of similarity was calculated 10,000 times with the same number of individuals in each group as the original dataset. $P$-values were calculated as the percentage of iterations that resulted in an similarity index smaller than observed [32, 45]. Finally, to assess relative density of birds and overall distributions, densities were calculated from the last chain of the MCMC estimation for each individual over a $5 \times 5 \mathrm{~km}$ grid (to aid in visualization). This method incorporates the uncertainty in the location estimates and negates the reasons to use a method such as a kernel density estimate $[40,46]$.

\section{Individual Spatial Fidelity}

Area fidelity can occur at varying spatial scales. To identify the spatial scales in which kittiwakes showed fidelity to wintering areas we calculated a monthly index of similarity, a measure of the number of shared grid cells, between all estimated locations for repeat trips from individual birds $(n=17)$ at a series of grid sizes ranging from $10-400 \mathrm{~km}$. Then to quantify a random measure of overlap we calculated the percentage of overlap between 59 random pairs, between individuals of the same sex and colony from consecutive years.

\section{Annual difference in large marine ecosystem use}

To better understand annual changes in large-scale distributions and habitat use of kittiwakes we assessed the use of oceanic biogeographical provinces of the North Pacific [9]. For each province, at the scale of $45 \mathrm{~km}$ grid cells, we calculated the percentage of the biogeographic province occupied by kittiwakes (again incorporating location error by using the last chain of the MCMC estimates) (\# grid cells occupied/total grid cells in province), average density of occupied grid cells, and the proportion of the overall bird distribution in each province (\# grid cells occupied inside region/total \# grid cells occupied). We also assessed how individuals used these regions by calculating the number of ecoregions used by individual birds and by sexes.

\section{Annual habitat conditions}

Habitat variables were extracted along the best-fit tracks at a $1^{\circ}$ grid scale. Sea surface temperatures (SST) were extracted as an eight-day blended product from data hosted by NOAA's Environmental Research Division (http://oceanwatch.pfeg.noaa.gov/thredds/catalog.html). Bathymetry was extracted from the ETOPO1 dataset [47], and bathymetric slope calculated. As eddies are known to condense prey for surface foraging predators including kittiwakes [28, 48], we extracted sea surface height (SSH) and surface currents used to calculate eddy kinetic energy (EKE) were extracted from the Navy Layered Ocean Model (1/32 ${ }^{\circ}$, http://www7320.nrlssc. navy.mil/global_nlom/) using the nctoolbox (https:// github.com/nctoolbox). We calculated the distance to eddy edge using mesoscale eddy trajectories [49]. Distance to productive seamounts or knolls, defined as those within $1500 \mathrm{~m}$ of the sea surface, was calculated for each bird location, as these features are known to enhance biological productivity [50, 51]. Monthly composites of 
MODIS-Aqua chlorophyll a, spanning 2007-2012, were constructed using DINEOF 3.0 to interpolate regions where clouds obscured satellite data [52]. Locations were matched to monthly composites, with locations from the first week of each month assigned to the previous month. Wind speed was extracted from the RNCEP Reanalysis II data sets for surface values $[53,54]$.

\section{Residency time}

We used residency time to understand the influence of habitat variability on individual movements. We chose this parameter rather than using a metric of foraging based on wet-dry data [32], as kittiwakes can employ both active and sit-and-wait foraging styles [55]. Residency time can be defined as the cumulative amount of time an individual animal spends within a circle of constant radius over a period of time [56]. In our case, we chose a radius of $45 \mathrm{~km}$, as this is rougly equivelant to the mean daily distance kittiwakes traveled over the whole non-breeding period (September-May), and a time constraint of 1 month to avoid false positives if individuals crossed over their own path months later on the return trip. High residency locations, indicating periods of intense search effort, were then chosen as the upper quartile of each individual's residency times [57].

\section{Habitat selection models}

Linear-mixed models were used to relate residency time to oceanic habitat characteristics in the top four biogeographic regions frequented by kittiwakes. Variance inflation factors were calculated, but all were $<3$, so all explanatory variables were retained [58]. To meet the conditions of normality for linear models residency time and chlorophyll a were log transformed and distance to eddy and bathymetric slope were square-root transformed. Best-fit models for each ecosystem were constructed using a reductive approach and identified from Akaike Information Criterion (AIC) scores based on restricted maximum likelihood estimates [58]. Individual was included as a random effect. Marginal $R^{2}$ values were used to describe the variance explained by the fixed effects and conditional $R^{2}$ values, the combined fixed and random effects $[59,60]$.

\section{Results}

Kittiwakes from the Pribilof Islands wintered predominantly across the deep oceanic waters of the central and western subarctic North Pacific all three years (Fig. 1). Area use of individual birds did not significantly differ between years, sexes, or colonies $(1,557,000 \pm 358,000$ $\mathrm{km}^{2}, p>0.05$; Table 2). As a group, females covered more area than males (Figs. 2 and 3). There was no difference in the size of cumulative area covered by birds from the two study colonies up to 40 individuals $(n=40$,
St Paul: 12,328,000, St George: 12,235,000), however at this point the lines diverge suggesting more low level variation in area use occurred among St. Paul birds $(n=53$, St Paul: 13,241,000, St George: 12,235,000; Figs. 2 and 3). Only birds from St. Paul used areas of the northwestern Bering Sea (Fig. 3). The amount of overlap between groups was not different than random for colonies (72\% overlap, $p=0.113$ ) and marginally different between sexes (70\% overlap, $p=0.06)$. Yearly combinations all showed less overlap between the observed distributions than randomly grouped tracks (2008/09 vs. $2009 / 10,63 \%$ overlap, $p<0.001 ; 2009 / 10$ vs. 2010/11, $56 \%$ overlap, $p<0.001 ; 2008 / 09$ vs. 2010/11, $61 \%$ overlap, $p=0.001$ ). A small number of birds, all females $(n=5)$, traveled east to the California Current System. Overall, kittiwakes showed a wide variety in wintering routes (Fig. 4).

\section{Scale of Individual Spatial Fidelity}

Birds that were tracked for two winters showed a tendency to return to the same regions and, for example, had on average $9 \%$ overlapping grid squares for $100 \times$ $100 \mathrm{~km}$ grid squares. During the mid-winter period (October - February) birds showed site fidelity at all scales, as the amount of shared grid cells was higher for individual bird repeat trips than for randomly paired tracks (Fig. 3). Some individuals repeated very unique routes, for instance, one bird traveled to the northern Bering Sea in the fall and then foraged along the Emperor Sea Mounts before heading back to the vicinity of the Pribilof Islands (Fig. 5).

\section{Annual difference in large marine ecosystem use}

Wintering Pribilof kittiwakes used seven biogeographical regions of the North Pacific (Table 3). On average $89.3 \pm$ $4.4 \%$ of the area kittiwakes used occurred in four of these, Epicontinental Seas (Bering Sea and Sea of Okhotsk-with little use of the Sea of Okhotsk), Western Subarctic Gyre (PSAW), Eastern Subarctic Gyre (PSAE), and the Polar Front (NPPF). Though geographically close to the Pribilof Islands, kittiwakes hardly used the Alaska Coastal Downwelling region ( $<3 \%$ of bird distributions). In all three years, kittiwakes used almost the entire area of the PSAW, while distributions only occupied a portion of all other biogeographical regions (Table 3). The highest densities of tracked kittiwakes also occurred in the PSAW (Table 3). Annual differences were apparent in regards to when kittiwakes occupied each of the main ecoregions; specifically in October and November of 2009/10 there was a notable increase in the continued use of the Bering Sea (Fig. 3). The change occurred because $70 \%$ of birds remained in the Bering Sea in the fall, which corresponded with lower October sea surface temperatures than the other two years (Table 4). In both 2008/09 and 2009/10, Dec-Feb, over 

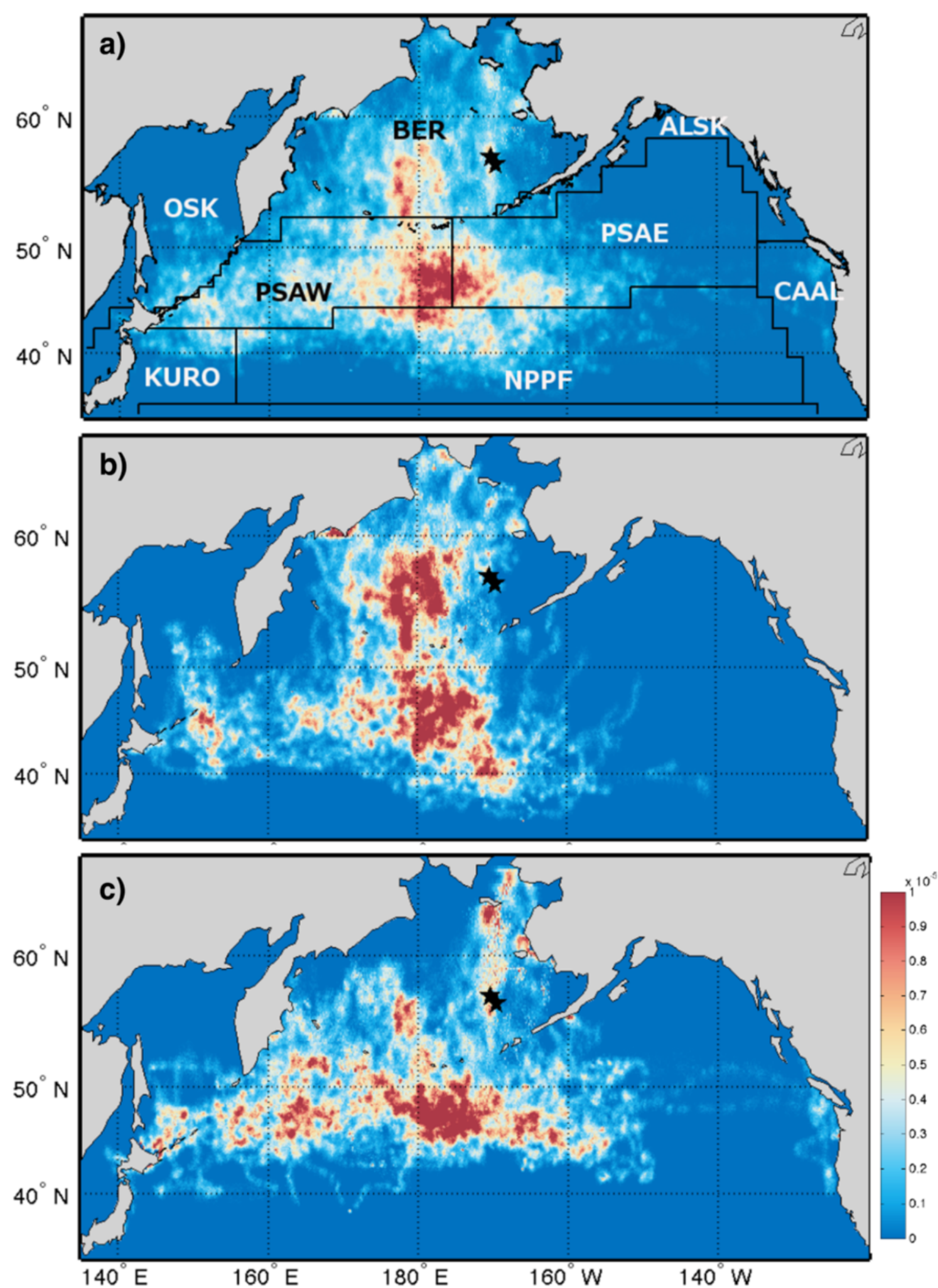

Fig. 1 Annual distribution of black-legged kittiwakes (Rissa tridactyla) from the Pribilof Islands during their central wintering period (October thru February). In a 2008/09 ( $n=38)$, b 2009/10 ( $n=44)$, and c 2010/11 ( $n=33)$. The boundaries of the ecoregions are shown following Longhurst, 2010, with the Bering Sea [BER] and Sea of Oskhosk [OSK] separated into two subregions. Remaining abbreviations are as follows: ALSK= Alaska Coastal Downwelling Zone, $\mathrm{CAAL}=$ California Current, $\mathrm{KURO}=$ Kuroshio Current, NPPF = North Pacific Polar Front, PSAE = Eastern Subarctic Gyre, PSAW = Western Subarctic Gyre 
Table 2 Yearly summary of winter space use for black-legged kittiwakes (Rissa tridactyla) from the Pribilof Islands (October thru February, 2008-2011)

\begin{tabular}{llll}
\hline & $2008 / 09$ & $2009 / 10$ & $2010 / 11$ \\
\hline \# of birds St Paul [male / female] & $19[7 / 12]$ & $26[12 / 14]$ & $15[3 / 12]$ \\
\# of birds St George [male / female] & $17[7 / 10]$ & $18[10 / 8]$ & $18[6 / 12]$ \\
Daily distance traveled (km)* & $35.4 \pm 3.5$ & $32.1 \pm 2.3$ & $34.5 \pm 2.8$ \\
Max distance from colony (km) & $2,573 \pm 682$ & $2,508 \pm 625$ & $2,601 \pm 798$ \\
Individual Area use (\# 45 km grid cells) & $811 \pm 226$ & $726 \pm 120$ & $781 \pm 172$ \\
Residency (days) & $2.17 \pm 0.35$ & $2.45 \pm 0.45$ & $2.09 \pm 0.37$ \\
\hline
\end{tabular}

*year: $\mathrm{F}=14.25, p<0.001$

$30 \%$ of bird locations were in the NPPF; while in 2010/11 the majority of locations during these months were farther north in the PSAW (Fig. 6). On average individual kittiwakes used $4.9 \pm 1$ ecoregions and this did not differ between sex, or year, however only female kittiwakes traveled to the California Current and birds from St Paul used fewer ecoregions (4.6 \pm 1$)$ than birds from St George $(5.3 \pm 0.08)$ (Fig. 7).

\section{Habitat conditions and selection}

Throughout the winter, kittiwakes experienced a broad range of habitat conditions. Sea surface temperatures were on average $6.3 \pm 2.6^{\circ} \mathrm{C}$ (daily individual range: $-1.7-$ $\left.14.8^{\circ} \mathrm{C}\right)$, chlorophyll a $1.32 \pm 4.08 \mathrm{mg} \mathrm{m}^{-3}(0.25-62.67 \mathrm{mg}$ $\left.\mathrm{m}^{-3}\right)$, EKE $63.9 \pm 45.4 \mathrm{~cm}^{2} \mathrm{~s}^{-2}\left(5.8-437.2 \mathrm{~cm}^{2} \mathrm{~s}^{-2}\right), \mathrm{SSH}$ $-8.9 \pm 8.3 \mathrm{~cm}(-26.3-20.2 \mathrm{~cm})$. While annual differences in habitat conditions existed, differences in habitat conditions between ecoregions were more pronounced (Table 3). Habitat variables were not a good predictor of residency in each ecoregion, with the best models only explaining $<15 \%$ of the variation (Table 5 ).

\section{Discussion}

Kittiwakes from the Pribilof Islands underwent extensive pelagic migrations to diverse subarctic biogeographical regions in North Pacific. Both sex and past experience appeared to influence where individuals wintered. However, individuals displayed a large amount of flexibility and annual changes in distributions were larger than differences observed between sexes or colonies. As generalist predators kittiwakes are likely adapted to a high amount of environmental variability.

\section{Interplay of intrinsic influences}

The reasons for colony specific wintering areas are not always clear. In some cases these colony differences may arise as the result of differing local conditions altering the phenology of migrations or simply be the result of a range expansion from geographically separated colonies as birds are still tied to these at an annual or biennial time scale $[15,30,46,61,62]$. Alternatively there are examples where birds from different colonies winter in the same region $[61,63]$. The Pribilof colonies are only 70 $\mathrm{km}$ apart and the timing of breeding is highly synchronous [64]; thus it is not surprising that distributions of kittiwakes are similar. Yet, they are almost entirely distinct from wintering areas frequented by kittiwakes originating from Prince William Sound [33]. Therefore, there is likely additional colony associated variability in wintering areas across the North Pacific basin similar to that seen in kittiwakes in the North Atlantic [30].

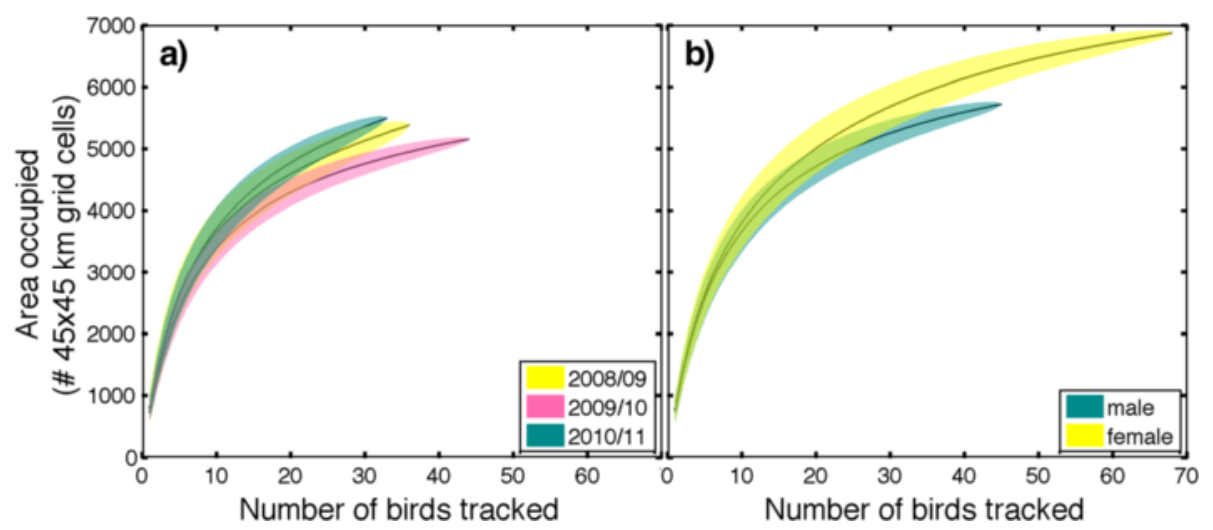

Fig. 2 Area occupied (number of $45 \mathrm{~km}^{2}$ grid cells) by migrating black-legged kittiwakes (Rissa tridactyla) from October thru February. By a) year where 2008/09 =yellow, 2009/10 = pink, and 2010/11 = green and b) sex (female=yellow, male = green) 


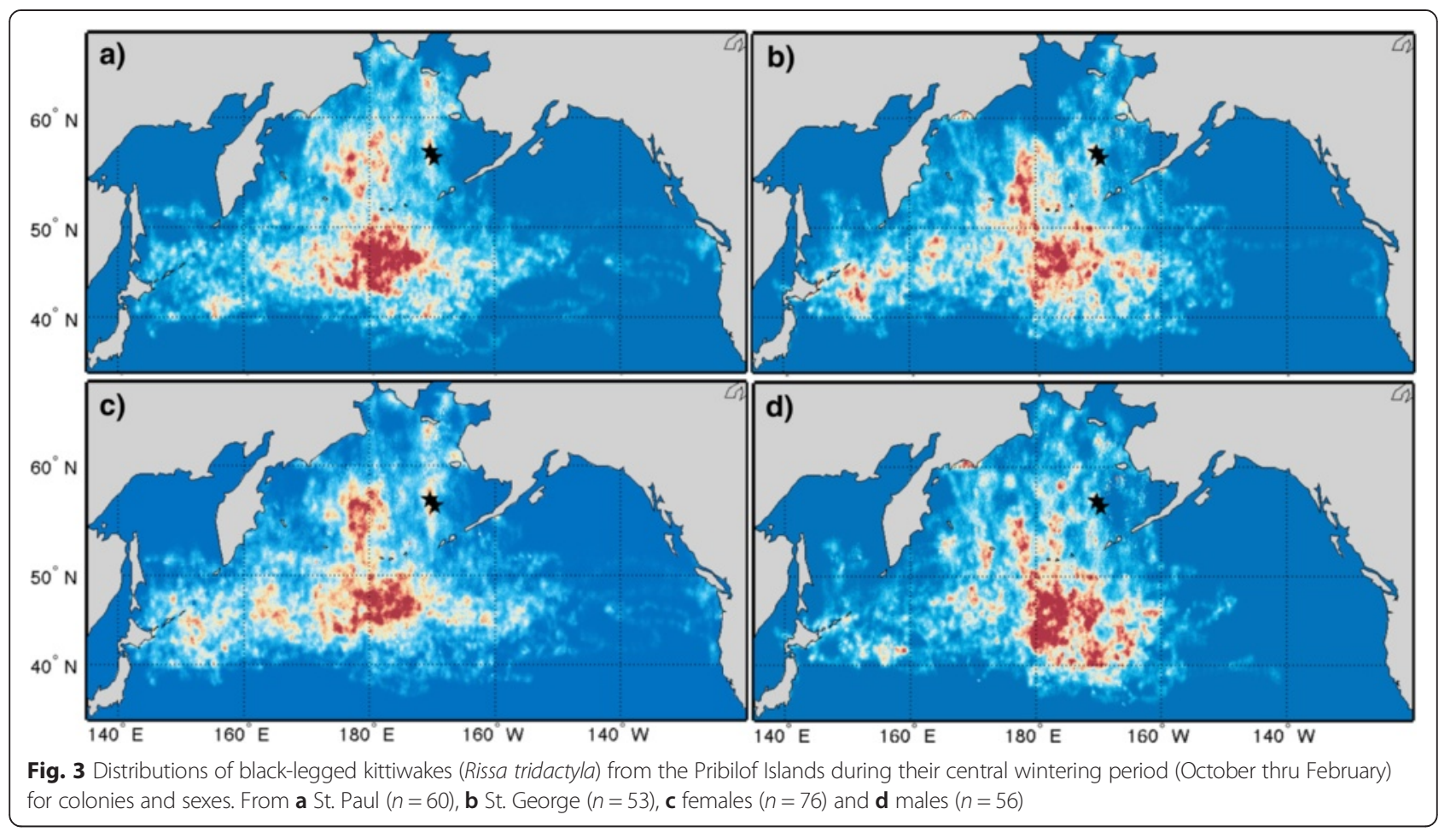

We found a slight effect of sex on wintering distributions; though area use was largely similar, females appear to be more dispersive and no males traveled to the California Current System. Sex differences in distributions are often linked to differences in timing relative to nest defense or breeding roles and niche partitioning in sexually dimorphic seabirds [65-67]. Black-legged kittiwake males are larger than females in body and bill size [32] and this may lead to differences in energetic requirements or foraging preferences that may influence

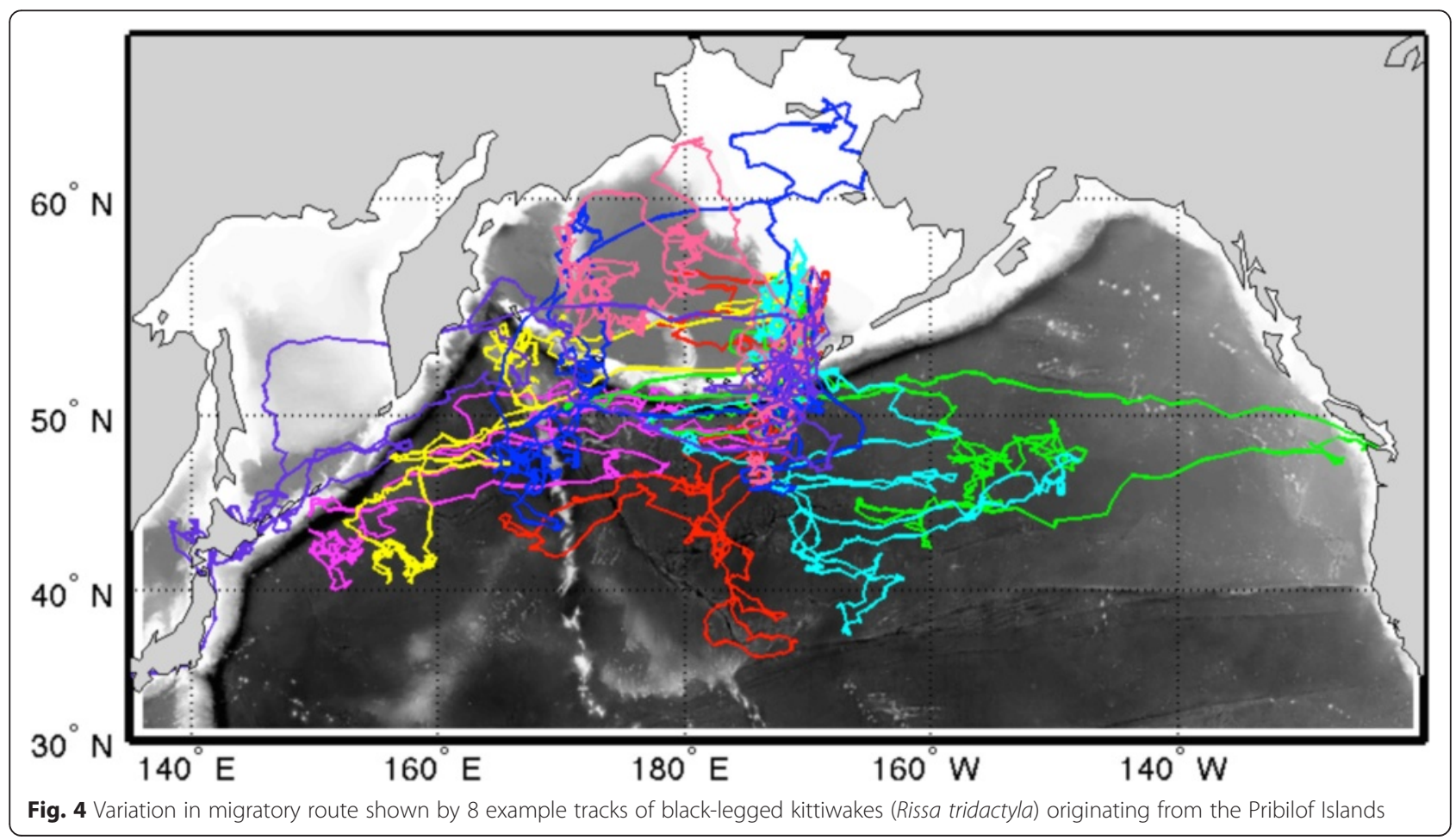




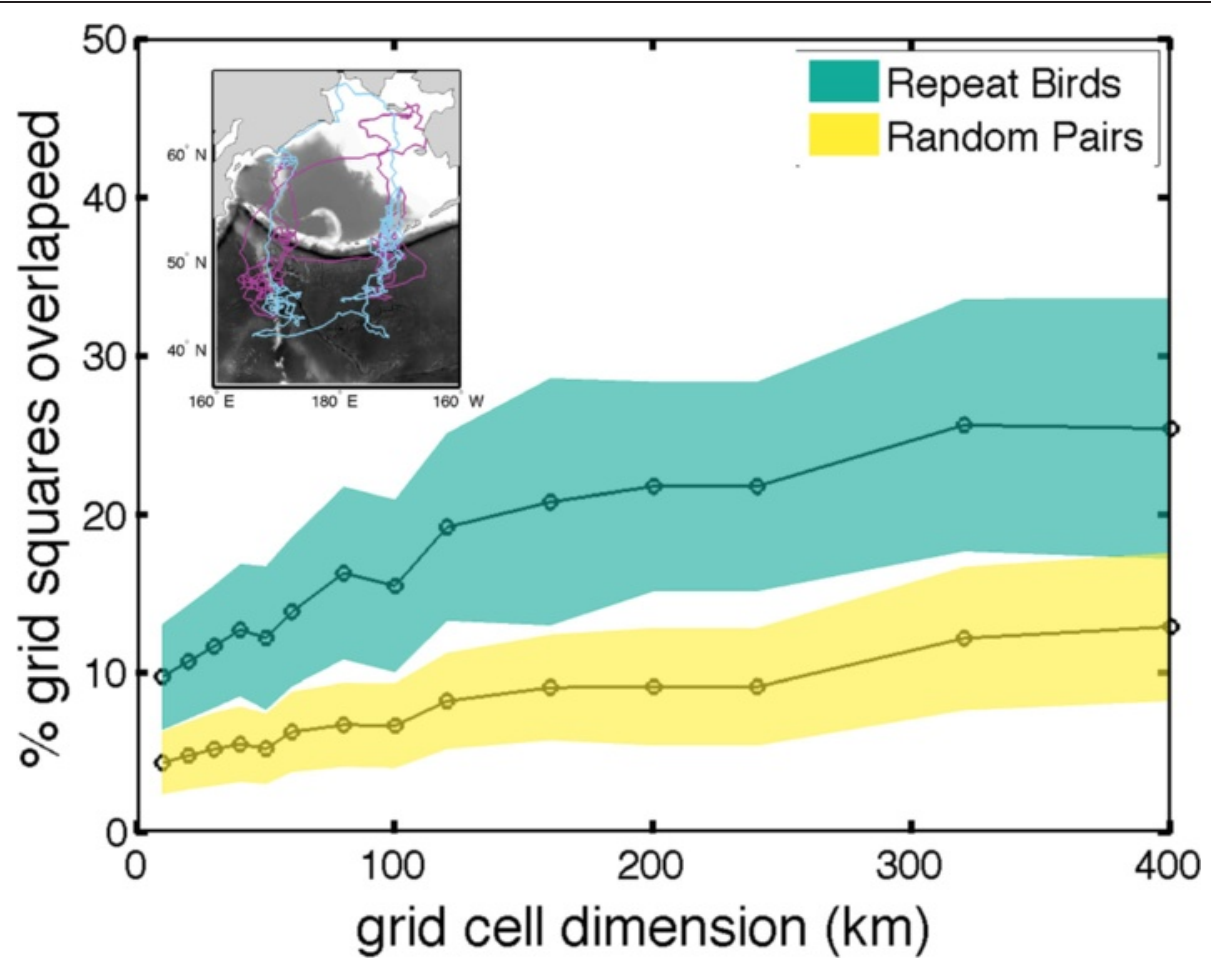

Fig. 5 Higher site fidelity in repeat migrations of 17 black-legged kittiwakes (Rissa tridactyla) during October thru February than randomly paired tracks $(n=59)$, of the same colony and sex. Inset: example track from a kittiwake breeding at St Paul where dark purple is 2009/10 and light blue is $2010 / 11$

wintering distributions. Additionally, there is ample evidence of sexual differences in behavior of kittiwakes during the breeding season [27, 68, 69], and that breeding outcome (or elevated stress levels) may carry over to affect the non-breeding distributions of one but not the other $\operatorname{sex}[29,70]$.

Fidelity during periods when individuals are constrained by central-place foraging, for instance in breeding seals and seabirds, appears to be relatively high $[40,71-73]$.
Much less is known about spatial fidelity when marine predators undergo migrations, often at the scale of ocean basins. Both flexibility and fidelity have been observed in migrating shearwaters, suggesting that individuals are able to explore and utilize multiple suitable wintering areas during a lifetime [24, 25]. Like migrating Atlantic puffins [20], black-legged kittiwakes displayed a tendency to return to areas that they frequented the year before. Both puffins and kittiwakes

Table 3 Annual occupancy of marine biogeographical ecoregions by migrating black-legged kittiwakes (Rissa tridactyla) from the Pribilof Islands (October thru February)

\begin{tabular}{|c|c|c|c|c|c|c|c|c|c|}
\hline & \multicolumn{3}{|c|}{ Average bird occupancy (\# birds / 45 km²) } & \multicolumn{3}{|c|}{ \% Ecoregion occupied } & \multicolumn{3}{|c|}{$\%$ bird distribution } \\
\hline & 2008/09 & 2009/10 & 2010/11 & 2008/09 & 2009/10 & 2010/11 & 2008/09 & 2009/10 & 2010/11 \\
\hline Epicontinental Seas: & $3.9 \pm 3.0$ & $6.6 \pm 5.3$ & $4.9 \pm 3.0$ & 38.8 & 56.2 & 62.9 & 16.1 & 24.4 & 25.6 \\
\hline Bering Sea & $4.3 \pm 3.2$ & $7.4 \pm 5.5$ & $5.6 \pm 3.0$ & 55.1 & 77.2 & 81.7 & 13.2 & 19.4 & 19.3 \\
\hline Sea of Okhotsk & $1.9 \pm 1.0$ & $3.4 \pm 2.2$ & $2.6 \pm 1.3$ & 14.9 & 29.0 & 35.5 & 2.8 & 5.7 & 6.6 \\
\hline Subarctic Gyre (West) & $8.5 \pm 4.3$ & $9.2 \pm 5.2$ & $7.6 \pm 4.0$ & 99.7 & 98.5 & 99.7 & 22.0 & 22.7 & 21.5 \\
\hline Subarctic Gyre (East) & $6.6 \pm 5.0$ & $5.3 \pm 5.6$ & $5.4 \pm 4.4$ & 58.0 & 39.2 & 79.9 & 16.5 & 11.6 & 22.2 \\
\hline Alaska Coastal Downwelling & $4.1 \pm 2.4$ & $1.4 \pm 1.0$ & $2.2 \pm 1.4$ & 20.5 & 12.1 & 34.5 & 1.4 & 0.8 & 2.2 \\
\hline Polar Front & $4.5 \pm 4.0$ & $4.9 \pm 4.2$ & $2.3 \pm 1.8$ & 53.4 & 53.2 & 25.6 & 34.0 & 35.3 & 15.9 \\
\hline California Current & $1.1 \pm 0.3$ & 0 & $1.5 \pm 0.7$ & 16.8 & 0 & 22.9 & 3.7 & 0 & 4.9 \\
\hline Kuroshio Current & $3.3 \pm 2.4$ & $1.9 \pm 1.1$ & $1.1 \pm 0.3$ & 21.1 & 12.4 & 22.6 & 5.5 & 3.4 & 5.8 \\
\hline
\end{tabular}


Table 4 Habitat characteristics of wintering locations for blacklegged kittiwakes (Rissa tridactyla) in the Bering Sea during October (2008, 2009, 2010)

\begin{tabular}{llll}
\hline & 2008 & 2009 & 2010 \\
\hline Residency Time (d) & $2.3 \pm 1.0$ & $2.9 \pm 1.1$ & $2.3 \pm 1.3$ \\
SST $\left({ }^{\circ} \mathrm{C}\right)$ & $6.2 \pm 0.8$ & $5.8 \pm 0.9$ & $7.1 \pm 1.4$ \\
Distance to Seamount $(\mathrm{km})$ & $474 \pm 241$ & $284 \pm 144$ & $438 \pm 329$ \\
SSH $(\mathrm{cm})$ & $-7.9 \pm 2.45$ & $-7.3 \pm 2.56$ & $-9.6 \pm 3.54$ \\
EKE $\left(\mathrm{cm}^{2} \mathrm{~s}^{-2}\right)$ & $66.8 \pm 34.7$ & $42.5 \pm 27.1$ & $48.3 \pm 23.1$ \\
Distance to Eddy (km) & $154 \pm 62$ & $139 \pm 76$ & $206 \pm 121$ \\
Chl a $\left(\mathrm{mg} \mathrm{m}^{-3}\right)$ & $1.61 \pm 1.30$ & $1.88 \pm 2.63$ & $3.0 \pm 4.44$ \\
Wind speed $\left(\mathrm{m} \mathrm{s}^{-1}\right)$ & $8.72 \pm 1.33$ & $8.71 \pm 1.02$ & $7.79 \pm 0.99$ \\
\hline
\end{tabular}

Means \pm SD are calculated from individual bird means

show characteristics of a dispersive migration, as routes often move gradually away from the breeding colony, rather than traveling to a distinct destination (see Fig. 4). However for kittiwakes, the amount of fidelity individuals showed was relatively small ( $25 \%$ of locations within $400 \mathrm{~km}$ grid squares) compared to the fidelity quantified for Atlantic puffins (median nearest neighbor distance $<5$ degrees) [20]. Kittiwakes are generalist predators that can only access the top $1 \mathrm{~m}$ of the water column, and they are much better fliers than puffins. Perhaps it is the combination of these life-history strategies that limits the amount of spatial fidelity that is advantageous, as prey resources can be patchy in pelagic environments [8]. Like puffins, it is unlikely that kittiwakes socially learn wintering areas as there is both individual fidelity and a high amount of variability within the population, instead it seems more likely that individuals rely on initial exploration, spatial memory and current conditions to inform travel paths. Our dataset is dominated by comparisons to 2009/10 when population level distributions were distinctly different from the other two years. This contrast likely led to less fidelity than might occur under similar conditions. More research is needed to understand if individuals are returning to areas where they previously experienced good foraging conditions and how fidelity changes when conditions change.

\section{Oceanographic habitats and annual conditions}

During all three of our study years the highest densities of wintering kittiwakes occurred in the central subarctic Pacific at the confluence of the Western Subarctic Gyre (PSAW) and the Eastern Subarctic Gyre (PSAE). This region, characterized by the subarctic current may support relatively high zooplankton biomass in the summer [74, 75]. Kittiwakes from the Pribilofs used the entire PSAW. The PSAW has higher primary productivity than the Gulf of Alaska [76], more intense eddy activity [77], and supports a greater diversity of myctophid species [78]; potentially providing a more predictable winter habitat than the other ecoregions. Annual changes in kittiwake distributions occurred at a much higher magnitude, measured by the amount of overlap, than differences between intrinsic groups (colony and sex), and this reflects the contrasting conditions that occurred during the three-study years. Even restricted to ecoregions our models relating residency time and environmental variables were not able to explain much of this relationship. It may be, that as generalists, kittiwakes are foraging on a diverse suite of prey (with variable preferences for oceanographic conditions) thus limiting the ability of these models to identify strong environmental associations. Or, as we are limited to the resolution of geolocation derived predator data, meaningful habitatkittiwake associations maybe operating at smaller scales (both spatial and temporal), then we are able to quantify $[28,79]$. Regardless, overall our results show that

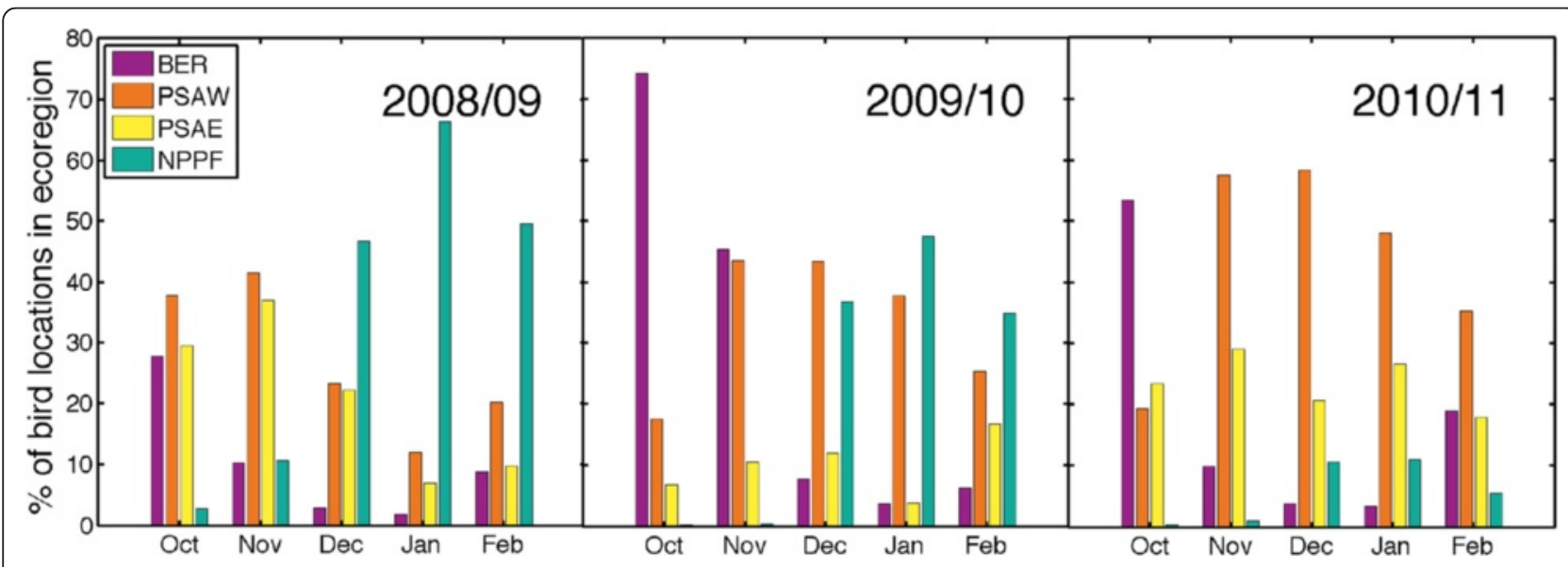

Fig. 6 Percentage of monthly bird locations in the four North Pacific ecoregions frequented most by wintering black-legged kittiwakes (Rissa tridactyla) from the Pribilof Islands 

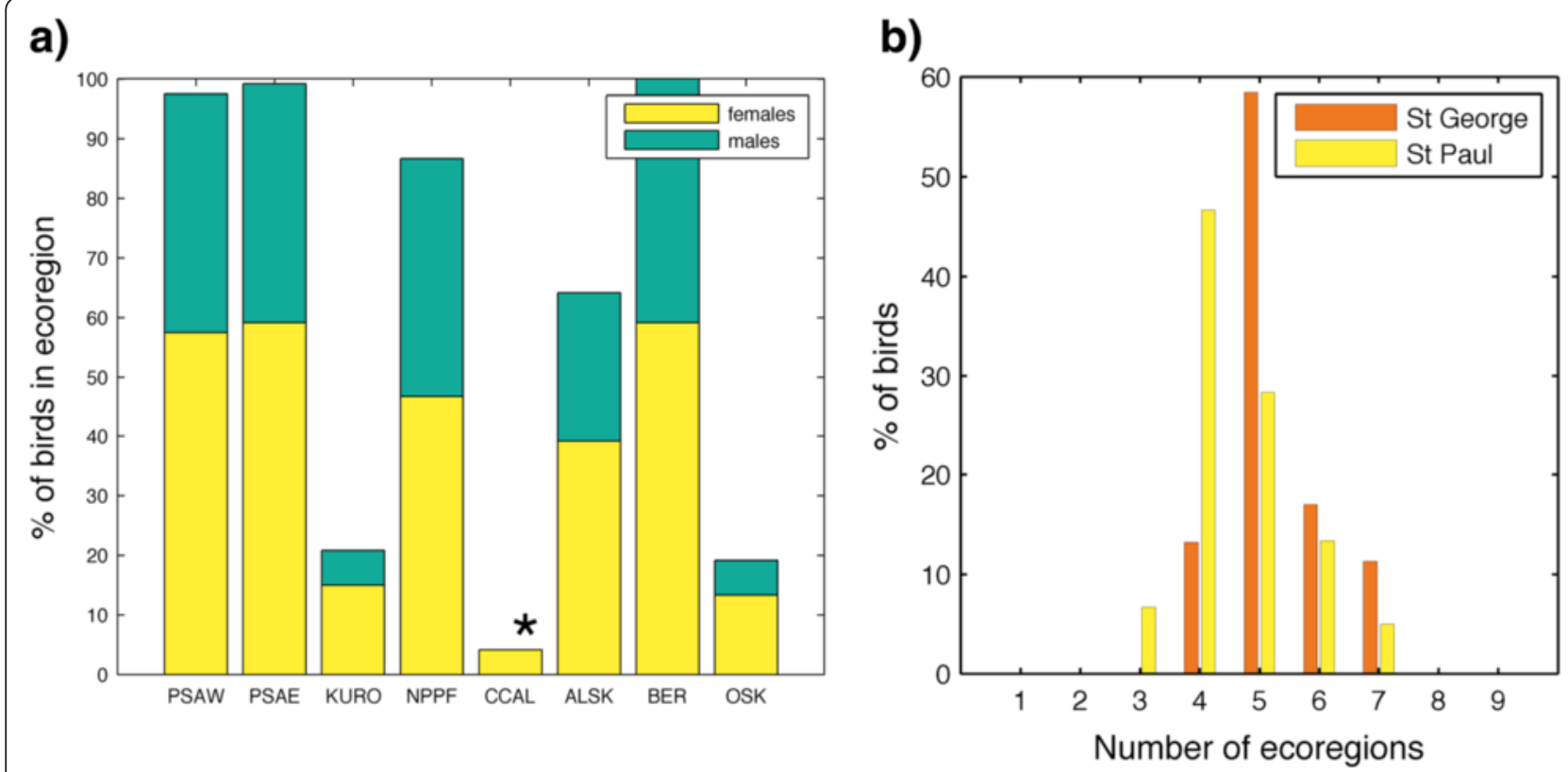

Fig. 7 Ecoregion use of black-legged kittiwakes (Rissa tridactyla). a Percent of black-legged kittiwakes using each ecoregion, with the proportion of males in green and females in yellow. The California Current (CCAL), denoted by an asterisk, was visited exclusively by female kittiwakes. Counts of males and females in each ecoregion are not significantly different than the overall sample (Chi squared, $p>0.05$ ). $\mathbf{b}$ Number of ecoregions used by individual birds from St Paul (yellow) and St George (orange)

Table 5 Summary statistics for linear mixed models of environmental influences on residency time for black-legged kittiwake (Rissa tridactyla) in each ecoregion

\begin{tabular}{lccccc}
\hline & df & AIC & $\Delta$ AIC & $R^{2}(m)$ & $R^{2}(c)$ \\
\hline Bering Sea & & & & & \\
Full model & 13 & 5504 & 7 & 0.005 & 0.149 \\
d2ed + EKE + d2hill + wind & 8 & 5497 & - & 0.004 & 0.150 \\
Subarctic Gyre (West) & & & & & \\
$\quad$ Full model & 13 & 13051 & 8 & 0.019 & 0.098 \\
SST + d2ed + wind & 7 & 13043 & - & 0.019 & 0.098 \\
Subarctic Gyre (East) & & & & & \\
$\quad$ Full model & 13 & 6129 & 10 & 0.028 & 0.071 \\
$\quad$ SST + d2hill & 6 & 6119 & - & 0.028 & 0.071 \\
Polar Front & & & & & \\
$\quad$ Full model & 13 & 8765 & 7 & 0.005 & 0.078 \\
d2ed + d2hill + chla & 7 & 8757 & - & 0.004 & 0.076 \\
\hline A &
\end{tabular}

All models include a temporal correlation term (corCAR1(form $=\sim$ date|id)). Summary statistics of each full model (SST + depth + d2ed + slopetrn + EKE + $\mathrm{ssh}+\mathrm{d} 2 \mathrm{hill}+$ wind $+\mathrm{chla}$ ) are presented first, followed by the best-fit model for each ecoregion. Akaike Information Criterion (AIC) were used to identify the best-fit model and marginal $R^{2}\left(R^{2}(m)\right)$ and conditional $R^{2}\left(R^{2}(c)\right)$ are presented. Abbreviations for the environmental variables used in the table are: sea-surface temperature (SST), distance to mesoscale eddy center (d2ed), sea-surface height (SSH), eddy kinetic energy (EKE), distance to productive seamounts and knolls (d2hill), monthly chlorophyll a (chla), bathymetric slope (slope) and bathymetry (bathy) multiple pelagic habitats are suitable for wintering kittiwakes.

In 2009/10, El Niño Modoki conditions occurred (central Pacific El Niño), characterized by a weakened Aleutian Low which is strengthened during a typical El Niño winter [80]. During this winter the western subarctic experienced anomalously high sea surface temperatures, while the central subarctic had anomalously cool sea surface temperatures [81]. The distribution of wintering kittiwakes in 2009/10 had a restricted longitudinal range and birds stayed much longer in the Bering Sea, potentially facilitated by colder sea surface temperatures (see Fig. 4 and Table 6), than during 2010/11, classified as strong La Niña year or 2008/09 classified as neutral conditions [82]. This shift to more northerly distributions in 2009/10 was also noted for wintering kittiwakes originating from the Shoup Bay colony in Prince William Sound [33]. This similar response suggests that during 2009/10 conditions suitable for wintering kittiwakes shifted northward across the North Pacific.

The winter of 2010/11, switched to one of strong La Niña conditions [83]. In the Gulf of Alaska, zooplankton biomass, survival estimates for age-1 pollock, and catch rates of juvenile pink salmon were all low [84, 85]. In 2010/11, kittiwakes spent much less time in the Polar Front region, however birds that did venture there did not experience conditions that were notably different from either of the other years, except for a 
Table 6 Habitat characteristics of wintering locations for black-legged kittiwakes (Rissa tridactyla) from October thru February in 2008/09, 2009/10, and 2010/11

\begin{tabular}{|c|c|c|c|}
\hline & 2008/09 & $2009 / 10$ & 2010/11 \\
\hline \multicolumn{4}{|l|}{ Bering Sea } \\
\hline Residency Time (d) & $2.1 \pm 1.0$ & $2.8 \pm 1.0$ & $2.0 \pm 0.8$ \\
\hline SST $\left({ }^{\circ} \mathrm{C}\right)$ & $4.65 \pm 2.2$ & $5.23 \pm 0.94$ & $5.87 \pm 1.85$ \\
\hline Distance to Seamount (km) & $455 \pm 285$ & $242 \pm 133$ & $362 \pm 230$ \\
\hline $\mathrm{SSH}(\mathrm{cm})$ & $-9.12 \pm 3.78$ & $-8.34 \pm 2.06$ & $-10.96 \pm 3.35$ \\
\hline $\operatorname{EKE}\left(\mathrm{cm}^{2} \mathrm{~s}^{-2}\right)$ & $70.4 \pm 35.9$ & $39.1 \pm 15.9$ & $54.6 \pm 27.2$ \\
\hline Distance to Eddy Edge (km) & $143 \pm 71$ & $131 \pm 48$ & $169 \pm 84$ \\
\hline $\mathrm{Chl} \mathrm{a}\left(\mathrm{mg} \mathrm{m}^{-3}\right)$ & $1.40 \pm 0.99$ & $1.68 \pm 2.21$ & $2.25 \pm 2.79$ \\
\hline Wind speed $\left(\mathrm{m} \mathrm{s}^{-1}\right)$ & $9.17 \pm 1.39$ & $8.94 \pm 0.70$ & $8.49 \pm 1.48$ \\
\hline \multicolumn{4}{|l|}{ Subarctic Gyre (West) } \\
\hline Residency Time (d) & $2.0 \pm 0.7$ & $2.2 \pm 0.9$ & $2.0 \pm 0.5$ \\
\hline SST $\left({ }^{\circ} \mathrm{C}\right)$ & $7.75 \pm 1.95$ & $5.61 \pm 1.78$ & $5.33 \pm 1.17$ \\
\hline Distance to Seamount (km) & $392 \pm 130$ & $357 \pm 118$ & $348 \pm 114$ \\
\hline $\mathrm{SSH}(\mathrm{cm})$ & $-17.99 \pm 3.28$ & $-14.83 \pm 2.15$ & $-15.49 \pm 3.0$ \\
\hline $\operatorname{EKE}\left(\mathrm{cm}^{2} \mathrm{~s}^{-2}\right)$ & $49.4 \pm 19.1$ & $58.9 \pm 18.2$ & $59.0 \pm 28.4$ \\
\hline Distance to Eddy $(\mathrm{km})$ & $127 \pm 29$ & $124 \pm 21$ & $114 \pm 11$ \\
\hline $\mathrm{Chl} \mathrm{a}\left(\mathrm{mg} \mathrm{m}^{-3}\right)$ & $0.63 \pm 0.22$ & $0.55 \pm 0.13$ & $0.66 \pm 0.32$ \\
\hline Wind speed $\left(\mathrm{m} \mathrm{s}^{-1}\right)$ & $8.85 \pm 1.52$ & $9.64 \pm 1.25$ & $9.46 \pm 0.90$ \\
\hline \multicolumn{4}{|l|}{ Subarctic Gyre (East) } \\
\hline Residency Time (d) & $2.0 \pm 0.7$ & $2.1 \pm 0.8$ & $1.8 \pm 0.7$ \\
\hline SST $\left({ }^{\circ} \mathrm{C}\right)$ & $7.82 \pm 1.34$ & $6.33 \pm 1.54$ & $6.58 \pm 1.22$ \\
\hline Distance to Seamount (km) & $766 \pm 221$ & $770 \pm 228$ & $744 \pm 192$ \\
\hline $\mathrm{SSH}(\mathrm{cm})$ & $-14.78 \pm 5.39$ & $-10.79 \pm 3.48$ & $-13.55 \pm 2.89$ \\
\hline $\operatorname{EKE}\left(\mathrm{cm}^{2} \mathrm{~s}^{-2}\right)$ & $38.6 \pm 12.6$ & $58.9 \pm 76.0$ & $44.3 \pm 34.4$ \\
\hline Distance to Eddy (km) & $152 \pm 35$ & $163 \pm 40$ & $147 \pm 37$ \\
\hline $\mathrm{Chl} \mathrm{a}\left(\mathrm{mg} \mathrm{m}^{-3}\right)$ & $0.64 \pm 0.28$ & $0.48 \pm 0.20$ & $0.50 \pm 0.21$ \\
\hline Wind speed $\left(\mathrm{m} \mathrm{s}^{-1}\right)$ & $9.31 \pm 1.70$ & $9.49 \pm 2.13$ & $9.77 \pm 2.07$ \\
\hline \multicolumn{4}{|l|}{ Polar Front } \\
\hline Residency Time (d) & $2.1 \pm 0.6$ & $2.0 \pm 0.5$ & $1.9 \pm 1.3$ \\
\hline SST $\left({ }^{\circ} \mathrm{C}\right)$ & $9.67 \pm 1.22$ & $8.50 \pm 1.43$ & $8.83 \pm 1.68$ \\
\hline Distance to Seamount (km) & $119 \pm 390$ & $122 \pm 324$ & $131 \pm 325$ \\
\hline $\mathrm{SSH}(\mathrm{cm})$ & $2.78 \pm 6.72$ & $5.30 \pm 7.91$ & $-0.89 \pm 4.72$ \\
\hline $\operatorname{EKE}\left(\mathrm{cm}^{2} \mathrm{~s}^{-2}\right)$ & $75.2 \pm 23.8$ & $67.7 \pm 18.9$ & $55.3 \pm 32.5$ \\
\hline Distance to Eddy (km) & $119 \pm 21$ & $122 \pm 22$ & $131 \pm 42$ \\
\hline $\mathrm{Chl} \mathrm{a}\left(\mathrm{mg} \mathrm{m}^{-3}\right)$ & $0.35 \pm 0.05$ & $0.32 \pm 0.05$ & $0.32 \pm 0.06$ \\
\hline Wind speed $\left(\mathrm{m} \mathrm{s}^{-1}\right)$ & $9.76 \pm 0.95$ & $9.91 \pm 0.84$ & $9.19 \pm 2.61$ \\
\hline
\end{tabular}

Yearly means \pm SD are calculated from individual bird means in each ecoregion

marked decrease in EKE. Eddies and surface currents are known to condense and facilitate prey capture for surface foraging seabirds $[28,79]$, thus is may be that this difference is linked to lower use. Relative to 2008/09 the more northerly distributions in 2009/10, when birds used the Bering Sea more, and in 2010/11 when kittiwake range in the subarctic was decreased, could be closer to what kittiwake wintering distributions may be like in the future.

Climate change is predicted to shift the North Pacific Transition Zone farther north, causing the subarctic zone south of the Aleutians to shrink in size [86]. This shift in habitats is likely to be challenging for Hawaiian albatrosses as it moves preferred foraging areas farther 
from breeding colonies [87, 88]. For kittiwakes, these changes will shrink the area of available wintering habitat, initially to a greater extent than what will open up to the north (due to the presence of land). Furthermore, in the North Pacific, Russian stocks of pink salmon (Oncorhynchus gorbuscha) currently follow a predictable alternation between large and small cohorts [89]. During large cohort years, prey availability is suppressed and across the North Pacific blacklegged kittiwakes respond through later hatch dates, lower laying success, smaller clutch size, and lower overall reproductive productivity-these effects appear to diminish in colonies in the Gulf of Alaska [89]. A shrinking subarctic may exacerbate competition between pink salmon, other salmonids, and seabirds. This could then lead to density dependent regulation of kittiwake populations, particularly if winter day length limits how far north kittiwakes can remain during the winter [90].

Though black-legged kittiwakes wintering in the pelagic North Pacific are able to retain spatial memories from one year to the next they also appear to have a high capacity to shift distributions in relationship to annual conditions. It remains unknown how long spatial memories may persist and if these long-lived individuals are simply returning to areas visited in the more distant past. It is also unknown if individuals are targeting previously profitable foraging areas. We were unable to find strong associations between kittiwake residency time and oceanographic habitats. This may reflect the scale of our analysis or be a characteristic that highlights the capacity of blacklegged kittiwakes to use multiple wintering ecoregions, presumably foraging on different prey species across both space and time.

\section{Availability of supporting data}

Raw geolocation data are available from the North Pacific Research Board [91].

\section{Competing interests}

The authors declare that they have no competing interests.

\section{Authors' contributions}

RAO, DDR, and DBI conceived and designed the study. RAO and RP carried out the study. RAO analyzed the data. RAO wrote the paper with assistance from all co-authors.

\footnotetext{
Acknowledgements

This research was approved by the animal care and use committee of the University of California Santa Cruz (UCSC) and by permit from the USFWS. We are highly indebted to four years of field teams including N. Banfield, D. Cushing*, B. Drummond*, T. Hartin, J. Harley, S.D. Kildaw*, C. Kroeger, D. Lyons, K. McKay, B. Messengale, V. Patel, C. Poli, A. Santos, R. Steenweg, J. Warzybok*, and A. Will (an asterisk (*) indicates multi-year efforts). We sincerely thank the Alaska Maritime National Wildlife Refuge for their longterm efforts to monitor seabird populations in Alaska. We also thank R. Phillips for his advice, R. Young and A. Kitaysky who provided laboratory assistance in sexing study birds and R. Kudela who processed chlorophyll
}

data. Two anonymous reviewers greatly improved this work. This research was funded by the North Pacific Research Board (NPRB) project 911 to DBI, DDR and SAS and project B63 to DBI and DDR. RAO was supported by a UCSC Regents Fellowship, a NPRB Graduate Fellowship and a UCSC Chancellor's Dissertation Year Fellowship. This is NPRB contribution number 544.

\section{Author details}

'Department of Ocean Sciences, Long Marine Lab, University of California Santa Cruz, Santa Cruz, CA 95060, USA. 'Department of Fisheries and Wildlife, Oregon State University, Hatfield Marine Science Center, 2030 SE Marine Science Dr., Newport, OR 97365, USA. ${ }^{3}$ Department of Fisheries and Wildlife, 104 Nash Hall, Oregon State University, Corvallis, OR 97331-3803, USA. ${ }^{4}$ US Geological Survey-Oregon Cooperative Fish and Wildlife Research Unit, Oregon State University, 104 Nash Hall, Corvallis, OR 97331-3803, USA. ${ }^{5}$ U.S. Fish and Wildlife Service, 1011 East Tudor Road, MS 341, Anchorage, AK 99503, USA. ${ }^{6}$ Department of Biological Sciences, San Jose State University, One Washington Square, San Jose, CA 95192-0100, USA. ${ }^{7}$ Institute of Marine Sciences, Long Marine Lab, University of California Santa Cruz, California 95060, USA.

Received: 31 January 2015 Accepted: 16 April 2015

Published online: 21 October 2015

\section{References}

1. Bolnick DI, Svanbäck R, Fordyce JA, Yang LH, Davis JM, Hulsey CD, et al. The Ecology of Individuals: Incidence and Implications of Individual Specialization. Am Nat. 2003;161:1-28.

2. Tinker MT, Costa DP, Estes JA, Wieringa N. Individual dietary specialization and dive behaviour in the California sea otter: Using archival time-depth data to detect alternative foraging strategies. Deep Sea Research Part II: Topical Studies in Oceanography. 2007;54:330-42.

3. Woo KJ, Elliott KH, Davidson M, Gaston AJ, Davoren GK. Individual specialization in diet by a generalist marine predator reflects specialization in foraging behaviour. Journal of Animal Ecology. 2008;77:1082-91.

4. Fauchald P. Spatial interaction between seabirds and prey: review and synthesis. Mar Ecol Prog Ser. 2009;391:139-51.

5. Benoit-Bird KJ, Battaile BC, Heppell SA, Hoover B, Irons DB, Jones N, et al. Prey Patch Patterns Predict Habitat Use by Top Marine Predators with Diverse Foraging Strategies. PLoS ONE. 2013;8:e53348.

6. Nevitt G. Testing olfactory foraging strategies in an Antarctic seabird assemblage. Journal of Experimental Biology. 2004;207:3537-44.

7. Bodey TW, Jessopp MJ, Votier SC, Gerritsen HD, Cleasby IR, Hamer KC, et al. Seabird movement reveals the ecological footprint of fishing vessels. Current Biology. 2014;24:R514-5.

8. Weimerskirch $\mathrm{H}$. Are seabirds foraging for unpredictable resources? Deep Sea Research Part II: Topical Studies in Oceanography. 2007;54:211-23.

9. Longhurst AR. Ecological Geography of the Sea. Elsevier Inc: United States; 2010.

10. Shaffer SA, Tremblay Y, Weimerskirch H, Scott D, Thompson DR, Sagar PM, et al. Migratory shearwaters integrate oceanic resources across the Pacific Ocean in an endless summer. Proceedings of the National Academy of Sciences. 2006;103:12799-802.

11. Holyoak M, Casagrandi R, Nathan R, Revilla E, Spiegel O. Trends and missing parts in the study of movement ecology. Proceedings of the National Academy of Sciences. 2008;105:19060-5.

12. Nathan R, Getz WM, Revilla E, Holyoak M, Kadmon R, Saltz D, et al. A movement ecology paradigm for unifying organismal movement research. Proceedings of the National Academy of Sciences. 2008;105:19052-9

13. Tremblay Y, Thiebault A, Mullers R, Pistorius P. Bird-Borne Video-Cameras Show That Seabird Movement Patterns Relate to Previously Unrevealed Proximate Environment. Not Prey PLoS ONE. 2014;9:e88424.

14. Perez C, Granadeiro JP, Dias MP, Alonso H, Catry P. When males are more inclined to stay at home: insights into the partial migration of a pelagic seabird provided by geolocators and isotopes. Behavioral Ecology. 2014;25:313-9.

15. Rayner MJ, Hauber ME, Steeves TE, Lawrence HA, Thompson DR, Sagar PM, et al. Contemporary and historical separation of transequatorial migration between genetically distinct seabird populations. Nature Communications. 2011;2:332-7. 
16. Riotte-Lambert $L$, Weimerskirch $H$. Do naive juvenile seabirds forage differently from adults? Proceedings of the Royal Society B: Biological Sciences. 2013;280:20131434

17. Thiebot J-BB, Cherel Y, Crawford RJM, Makhado AB, Trathan PN, Pinaud D, et al. A Space Oddity: Geographic and Specific Modulation of Migration in Eudyptes Penguins. PLoS ONE. 2013;8:e71429.

18. Weimerskirch $\mathrm{H}$, Cherel Y, Delord K, Jaeger A, Patrick SC, Riotte-Lambert L. Lifetime foraging patterns of the wandering albatross: life on the move! Journal of Experimental Marine Biology and Ecology. 2014;450:68-78.

19. Croxall JP. Global Circumnavigations: Tracking Year-Round Ranges of Nonbreeding Albatrosses. Science. 2005;307:249-50.

20. Guilford T, Freeman R, Boyle D, Dean B, Kirk H, Phillips RA, et al. A Dispersive Migration in the Atlantic Puffin and Its Implications for Migratory Navigation. PLoS ONE. 2011;6:e21336.

21. Gutowsky SE, Tremblay Y, Kappes MA, Flint EN, Klavitter J, Laniawe L, et al. Divergent post-breeding distribution and habitat associations of fledgling and adult Black-footed Albatrosses Phoebastria nigripesin the North Pacific Ibis. 2013;156:60-72.

22. McFarlane Tranquilla LA, Montevecchi WA, Fifield DA, Hedd A, Gaston AJ, Robertson GJ, et al. Individual Winter Movement Strategies in Two Species of Murre (Uria spp.) in the Northwest Atlantic. PLoS ONE. 2014;9:e90583.

23. Phillips RA, Silk JRD, Croxall JP, Afanasyev V, Bennett VJ. Summer distribution and migration of nonbreeding albatrosses: Individual consistencies and implications for conservation. Ecology. 2005;86:2386-96.

24. Yamamoto T, Takahashi A, Sato K, Oka N. Individual consistency in migratory behaviour of a pelagic seabird. Behaviour. 2014;151:683-701.

25. Dias MP, Granadeiro JP, Phillips RA, Alonso H, Catry P. Breaking the routine: individual Cory's shearwaters shift winter destinations between hemispheres and across ocean basins. Proceedings of the Royal Society B: Biological Sciences. 2011;278:1786-93.

26. Baylis AMM, Orben RA, Pistorius P, Brickle P, Staniland I, Ratcliffe N. Winter foraging site fidelity of king penguins breeding at the Falkland Islands. Mar Biol. 2015;162:99-110.

27. Paredes $R$, Harding AMA, Irons DB, Roby DD, Suryan RM, Orben $R$, et al. Proximity to multiple foraging habitats enhances seabirds' resilience to local food shortages. Mar Ecol Prog Ser. 2012;471:253-69.

28. Paredes R, Orben RA, Suryan RM, Irons DB, Roby DD, Harding AMA, et al. Foraging Responses of Black-Legged Kittiwakes to Prolonged Food-Shortages around Colonies on the Bering Sea Shelf. PLoS ONE. 2014;9:e92520.

29. Bogdanova MI, Daunt F, Newell M, Phillips RA, Harris MP, Wanless S. Seasonal interactions in the black-legged kittiwake, Rissa tridactyla: links between breeding performance and winter distribution. Proc Biol Sci. 2011;278:2412-8

30. Frederiksen M, Moe B, Daunt F, Phillips RA, Barrett RT, Bogdanova MI, et al, Multicolony tracking reveals the winter distribution of a pelagic seabird on an ocean basin scale. Diversity and Distributions. 2011;18:530-42.

31. González-Solís J, Smyrli M, Militão T, Grémillet D, Tveraa T, Phillips RA, et al. Combining stable isotope analyses and geolocation to reveal kittiwake migration. Mar Ecol Prog Ser. 2011;435:251-61.

32. Orben RA, Irons DB. Paredes R, Roby DD, Phillips RA, Scott A Shaffer. North or south? Niche separation of endemic red-legged kittiwakes and sympatric black-legged kittiwakes during their non-breeding migrations. Journal of Biogeography. 2015;42:401-12.

33. McKnight A, Irons DB, Allyn AJ, Sullivan KM, Suryan RM. Winter dispersal and activity patterns of post-breeding black-legged kittiwakes Rissa tridactyla from Prince William Sound. Alaska Mar Ecol Prog Ser. 2011;442:241-53.

34. Irons DB. Foraging area fidelity of individual seabirds in relation to tidal cycles and flock feeding. Ecology. 1998;79:647-55.

35. Reiertsen TK, Erikstad KE, Anker-Nilssen T, Barrett RT, Boulinier T, Frederiksen $M$, et al. Prey density in non-breeding areas affects adult survival of blacklegged kittiwakes Rissa tridactyla. Mar Ecol Prog Ser. 2014;509:289-302.

36. Fridolfsson AK, Ellegren $\mathrm{H}$. A simple and universal method for molecular sexing of non-ratite birds. Journal of Avian Biology. 1999;30:116-21.

37. Elliott $\mathrm{KH}$, McFarlane-Tranquilla L, Burke CM, Hedd A, Montevecchi WA Anderson WG. Year-long deployments of small geolocators increase corticosterone levels in murres. Mar Ecol Prog Ser. 2012:466:1-7.

38. Vandenabeele SP, Shepard ELC, Grogan A, Wilson RP. When three per cent may not be three per cent; device-equipped seabirds experience variable flight constraints. Mar Biol Springer; 2012;159:1-14.

39. Ekstrom PA. An advance in geolocation by light. Mem Nat Inst Polar Res (Special Issue). 2004;58:210-26.
40. Sumner MD, Wotherspoon SJ, Hindell MA. Bayesian Estimation of Animal Movement from Archival and Satellite Tags. PLoS ONE. 2009;4:e7324

41. Thiebot J-BB, Pinaud D. Quantitative method to estimate species habitat use from light-based geolocation data. Endang Species Res. 2010;10:341-53.

42. Kotzerka J, Garthe S, Hatch SA. GPS tracking devices reveal foraging strategies of Black-legged Kittiwakes. J Ornithol. 2009;151:459-67.

43. Phillips RA, Silk JRD, Croxall JP, Afanasyev V, Briggs DR. Accuracy of geolocation estimates for flying seabirds. Mar Ecol Prog Ser. 2004;266:265-72.

44. Hindell MA, Bradshaw CJA, Sumner MD, Michael KJ, Burton HR. Dispersal of female southern elephant seals and their prey consumption during the austral summer: relevance to management and oceanographic zones. J Appl Ecology. 2003;40:703-15.

45. Breed GA, Bowen WD, McMillan Jl, Leonard ML. Sexual segregation of seasonal foraging habitats in a non-migratory marine mammal. Proceedings of the Royal Society B: Biological Sciences. 2006;273:2319-26.

46. Ratcliffe N, Crofts S, Brown R, Baylis AMM, Adlard S, Horswill C, et al. Love thy neighbour or opposites attract? Patterns of spatial segregation and association among crested penguin populations during winter. J Biogeogr 2014:41:1183-92.

47. Smith WH. Global Sea Floor Topography from Satellite Altimetry and Ship Depth Soundings. Science. 1997;277:1956-62.

48. Bost C-A, Cotté C, Bailleul F, Cherel Y, Charrassin J-B, Guinet C, et al. The importance of oceanographic fronts to marine birds and mammals of the southern oceans. J Mar Syst. 2009;78:363-76.

49. Chelton DB, Schlax MG, Samelson RM. Global observations of nonlinear mesoscale eddies. Prog Oceanogr. 2011;91:167-216.

50. Yesson C, Clark MR, Taylor ML, Rogers AD. The global distribution of seamounts based on 30 arc seconds bathymetry data. Deep-Sea Research Part I. 2011;58:442-53.

51. Bouchet PJ, Meeuwig JJ, Kent S, Chandra P, Letessier TB, Jenner CK. Topographic determinants of mobile vertebrate predator hotspots: current knowledge and future directions. Biol Rev. 2015;90:699-728.

52. Beckers J-M, Rixen M. EOF Calculations and Data Filling from Incomplete Oceanographic Datasets. J Atmos Oceanic Tech. 2003;20:1839-56.

53. Kanamitsu M, Ebisuzaki W, Woolen J, Yang SK, Hnilo JJ, Fiorino M, et al. NCEP-DOE AMIP-II reanalysis (R-2). Bull Am Meteorol Soc. 2002;83:1631-43.

54. Kemp MU, Emiel van Loon E, Shamoun-Baranes J, Bouten W. RNCEP: global weather and climate data at your fingertips. Methods in Ecology and Evolution. 2011:3:65-70.

55. Jodice PGR, Roby DD, Suryan RM, Irons DB, Kaufman AM, Turco KR, et al. Variation in Energy Expenditure among Black-Legged Kittiwakes: Effects of Activity-Specific Metabolic Rates and Activity Budgets. Physiol Biochem Zool. 2003;76:375-88.

56. Barraquand F, Benhamou S. Animal movements in heterogeneous landscapes: identifying profitable places and homogeneous movement bouts. Ecology. 2011;89:3336-48.

57. Torres LG, Thompson DR, Bearhop S, Votier S, Taylor GA, Sagar PM, et al. White-capped albatrosses alter fine-scale foraging behavior patterns when associated with fishing vessels. Mar Ecol Prog Ser. 2011;428:289-301.

58. Zuur AF, leno EN, Walker NJ, Saveliev AA, Smith GM. Mixed effects models and extensions in ecology with R. Milton Keynes. United Kingdom: Springer; 2009.

59. Nakagawa $S$, Schielzeth $H$. A general and simple method for obtaining $R^{2}$ from generalized linear mixed-effects models. O'Hara RB, editor. Methods in Ecology and Evolution. 2012;4:133-42.

60. Xu R. Measuring explained variation in linear mixed effects models. Statist Med. 2003:22:3527-41.

61. McFarlane Tranquilla LA, Montevecchi WA, Hedd A, Fifield DA, Burke CM, Smith PA, et al. Multiple-colony winter habitat use by murres Uria spp. in the Northwest Atlantic Ocean: implications for marine risk assessment. Mar. Ecol. Prog. Ser. 2013;472:287-303.

62. Thiebot J-BB, Cherel Y, Trathan PN, Bost C-A. Coexistence of oceanic predators on wintering areas explained by population-scale foraging segregation in space or time. Ecology Eco Soc America. 2012;93:122-30.

63. González-Solís J, Croxall JP, Oro D, Ruiz X. Trans-equatorial migration and mixing in the wintering areas of a pelagic seabird. Frontiers in Ecology and the Environment Eco Soc America; 2007:5:297-301.

64. Byrd GV, Sydeman WJ, Renner HM, Minobe S. Responses of piscivorous seabirds at the Pribilof Islands to ocean climate. Deep Sea Research Part II: Topical Studies in Oceanography. 2008;55:1856-67. 
65. Thiebot J-BB, Authier M, Trathan PN, Bost C-A. Gentlemen first? "Broken stick" modelling reveals sex-related homing decision date in migrating seabirds. J Zool. 2014;292:25-30.

66. Thiebot J-BB, Cherel Y, Acqueberge M, Prudor A, Trathan PN, Bost C-A Adjustment of pre-moult foraging strategies in Macaroni Penguins Eudyptes chrysolophus according to locality, sex and breeding status. Ibis. 2014; 156:511-22.

67. Hedd A, Montevecchi WA, Phillips RA, Fifield DA. Seasonal Sexual Segregation by Monomorphic Sooty Shearwaters Puffinus griseus Reflects Different Reproductive Roles during the Pre-Laying Period. PLoS One. 2014;9:e85572

68. Roberts BD, Hatch SA. Behavioral Ecology of Black-Legged Kittiwakes during Chick Rearing in a Failing Colony. The Condor. 1993;95:330-42.

69. Jodice PGR, Roby DD, Turco KR, Suryan RM, Irons DB, Piatt JF, et al. Assessing the nutritional stress hypothesis: relative influence of diet quantity and quality on seabird productivity. Mar Ecol Prog Ser. 2006;325:267-79.

70. Schultner J, Moe B, Chastel O, Tartu S, Bech C, Kitaysky AS. Corticosterone mediates carry-over effects between breeding and migration in the kittiwake Rissa tridactyla. Mar Ecol Prog Ser. 2014;496:125-33.

71. Baylis AMM, Page B, McKenzie J, Goldsworthy SD. Individual foraging site fidelity in lactating New Zealand fur seals: Continental shelf vs. oceanic habitats. Marine Mammal Sci. 2011;28:276-94.

72. Patrick SC, Bearhop S, Grémillet D, Lescroël A, Grecian WJ, Bodey TW, et al. Individual differences in searching behaviour and spatial foraging consistency in a central place marine predator. Oikos. 2014;123:33-40.

73. Call KA, Ream RR, Johnson D, Sterling JT, Towell RG. Foraging route tactics and site fidelity of adult female northern fur seal (Callorhinus ursinus) around the Pribilof Islands. Deep Sea Research Part II: Topical Studies in Oceanography. 2008:55:1883-96.

74. Mackas DL, Tsuda A. Mesozooplankton in the eastern and western subarctic Pacific: community structure, seasonal life histories, and interannual variability. Prog Oceanogr. 1999:43:335-63.

75. Sugimoto T, Tadokoro K. Interdecadal variations of plankton biomass and physical environment in the North Pacific. Fish Oceanogr. 1998;7:289-99.

76. Saito R, Yamaguchi A, Saitoh SI, Kuma K, Imai I. East-west comparison of the zooplankton community in the subarctic Pacific during summers of 2003-2006. J Plankton Res. 2010;33:145-60.

77. Bograd SJ, Rabinovich AB, LeBlond PH, Shore JA. Observations of seamountattached eddies in the North Pacific. J Geophys Res Oceans. 1997;102:12441-56.

78. Beamish RJ, Leask KD, Ivanov OA, Balanov AA, Orlov AM, Sinclair B. The ecology, distribution, and abundance of midwater fishes of the Subarctic Pacific gyres. Prog Oceanogr. 1999;43:399-442.

79. Scales KL, Miller PI, Embling CB, Ingram SN, Pirotta E, Votier SC. Mesoscale fronts as foraging habitats: composite front mapping reveals oceanographic drivers of habitat use for a pelagic seabird. J R Soc Interface. 2014;11:20140679.

80. Weng H, Behera SK, Yamagata T. Anomalous winter climate conditions in the Pacific rim during recent El Niño Modoki and El Niño events. Clim Dyn. 2008;32:663-74.

81. Ratnam JV, Behera SK, Masumoto Y, Takahashi K, Yamagata T. Anomalous climatic conditions associated with the El Niño Modoki during boreal winter of 2009. Clim Dyn. 2011;39:227-38.

82. Wolter K, Timlin MS. El Niño/Southern Oscillation behaviour since 1871 as diagnosed in an extended multivariate ENSO index (MEl.ext). Int. J. Climatol. 2011;31:1074-87

83. Hu Z-Z, Kumar A, Xue Y, Jha B. Why were some La Niñas followed by another La Niña? Clim Dyn. 2014;42:1029-42.

84. Orsi JA, Sturdevant MV, Fergusson EA, Heinl SC, Vulstek SC, Maselko JM, et al. Connecting the "Dots" Among Coastal Ocean Metrics and Pacific Salmon Production in Southeast Alaska, 1997-2012. North Pacific Anadromous Fish Commission, Technical Report No 9. 2013:260-6

85. Zador SG, editor. Ecosystem Considerations 2013, Stock Assessment and Fishery Evaluation Report. Anchorage, Alaska: North Pacific Management Council; 2013. p. 1-236.

86. Polovina JJ, Dunne JP, Woodworth PA, Howell EA. Projected expansion of the subtropical biome and contraction of the temperate and equatorial upwelling biomes in the North Pacific under global warming. ICES Journal of Marine Science. 2011;68:986-95.
87. Hazen EL, Jorgensen S, Rykaczewski RR, Bograd SJ, Foley DG, Jonsen ID, et al. Predicted habitat shifts of Pacific top predators in a changing climate. Nature Climate Change. 2012;3:234-8.

88. Kappes MA, Shaffer SA, Tremblay Y, Foley DG, Palacios DM, Robinson PW, et al. Hawaiian albatrosses track interannual variability of marine habitats in the North Pacific. Prog Oceanogr. 2010;86:246-60.

89. Springer AM, van Vliet GB. Climate change, pink salmon, and the nexus between bottom-up and top-down forcing in the subarctic Pacific Ocean and Bering Sea. Proc Natl Acad Sci U S A. 2014;111:E1880-8.

90. Ballard G, Toniolo V, Ainley DG, Parkinson CL, Arrigo KR, Trathan PN. Responding to climate change: Adelie Penguins confront astronomical and ocean boundaries. Ecology. 2010;91:2056-69.

91. Orben R. Winter Ecology of Bering Sea Seabirds: Black-legged kittiwake geolocation light levels. 2008-2011. Anchorage, AK: North Pacific Research Board; 2015. Retrieved 03/11/2015 from http://s3.nprb.org/datasets/ ea46fd41-3ecc-4b00-b403-c55310c7a375/NPRB.2009.11.BLKI.LightLevels.xml.

\section{Submit your next manuscript to BioMed Central and take full advantage of:}

- Convenient online submission

- Thorough peer review

- No space constraints or color figure charges

- Immediate publication on acceptance

- Inclusion in PubMed, CAS, Scopus and Google Scholar

- Research which is freely available for redistribution 